\title{
The Farm in the City in the Recent Past: Thoughts on a More Inclusive Urban Historiography
}

Ruth Glasser

University of Connecticut, ruth.glasser@uconn.edu

Follow this and additional works at: https://opencommons.uconn.edu/ucsfacultywriting

Part of the American Studies Commons, Environmental Studies Commons, Food Studies $\underline{\text { Commons, }} \underline{\text { Social History Commons, United States History Commons, and the Urban Studies and }}$ Planning Commons

\section{Recommended Citation}

Glasser, Ruth, "The Farm in the City in the Recent Past: Thoughts on a More Inclusive Urban Historiography" (2017). Urban and Community Studies Faculty Writing. 1.

https://opencommons.uconn.edu/ucsfacultywriting/1 


\section{The Farm in the City in the Recent Past: Thoughts on a More Inclusive Urban Historiography}

Journal of Urban History

(c) The Author(s) 2017

Reprints and permissions: sagepub.com/journalsPermissions.nav DOI: $10.1177 / 0096 \mid 44216688906$ journals.sagepub.com/home/juh

@SAGE

\title{
Ruth Glasser ${ }^{\prime}$
}

\begin{abstract}
The scholarly and journalistic literature usually treats urban agriculture as a new phenomenon, but it is a neglected dimension of urban history. Some U.S. cities, at least in the Northeast, had food-raising and processing practices not just in colonial times but up until the relatively recent past. Three areas of history are explored that have mostly omitted discussion of city food production but nonetheless provide important frameworks to explore such production: urban development, agricultural, and immigrant history. Woven throughout this piece is evidence from a study of Waterbury, Connecticut. Local food production did not die when the Industrial Revolution came to Waterbury. Farms and other food-producing, processing, and marketing operations remained and even adapted to the growing city's needs and resources. The city government both supported and undermined agriculture in ways that add to an understanding of urban history and are lessons for current urban agriculture policy.
\end{abstract}

\section{Keywords}

urban farming, urban agriculture, Waterbury, Connecticut, agricultural history, urban development history

\begin{abstract}
American urban history conventionally traces the growth of cities, focusing in particular on the internal dynamics of expansion. Rarely have historians paid attention to what was lost, treating the landscape surrounding the core settlement as merely a city-waiting-to-happen. . . . A question that has largely remained a black box of urban history [is] exactly how did a major city embrace, enclose, and finally obliterate its surrounding farms?
\end{abstract}

—Marc Linder and Lawrence S. Zacharias (Of Cabbages and Kings County: Agriculture and the Formation of Modern Brooklyn $)^{1}$

In recent years, a veritable blizzard of scholarly and popular articles has addressed a trend currently known as "urban agriculture," defined as simply as "food production that occurs within city limits"2 or as complexly as

\footnotetext{
'University of Connecticut, Waterbury Campus, Waterbury, CT, USA
}

\section{Corresponding Author:}

Ruth Glasser, 99 East Main St., Waterbury, CT 0670, USA.

Email: ruth.glasser@uconn.edu 
an industry that produces, processes and markets food and fuel, largely in response to the daily demand of consumers within a town, city, or metropolis, on land and water dispersed throughout the urban and peri-urban area, applying intensive production methods, using and reusing natural resources and urban wastes, to yield a diversity of crops and livestock. ${ }^{3}$

Social scientists, planners, and community activists document urban agriculture in both the "developing countries" and the "developed." In the poorer nations, the narrative goes, robust farming and gardening is carried out by people who have migrated in massive numbers from rural areas and continue their subsistence practices as they occupy increasingly sprawling cities. ${ }^{4}$ In the meantime, in the richer countries, urban agriculture is the wave of the post-industrial future in places whose main asset may be "abundant vacant land left in the wake of people and economic activities moving from central cities to the suburbs." ${ }_{5}$ Local food production, write journalists, professors, and practitioners, can put vacant land to productive use, create jobs for impoverished urban residents while eliminating their food deserts, and reduce the enormous carbon footprint of modern industrial agriculture. ${ }^{6}$

What strikes a historian is the present-oriented tenor of this discussion, which either takes it for granted that urban agriculture in the United States is a new phenomenon or gives only a perfunctory nod to an urban agricultural past. An influential report on city farming by an urban planner and a landscape architect, for example, devotes only a paragraph to history-of community gardens, specifically - and suggests that U.S. cities can be "a new and unconventional locus for for-market farming ventures." A law student writes that "outdated zoning regulation can unintentionally impede urban agriculture," without questioning how and why those codes came to be in the first place. ${ }^{8}$ Much of the literature is also steadfastly non-U.S.-based, privileging best practices in the poorer nations as models for the wealthier, giving the undoubtedly inadvertent impression that there are no such potentially recoverable practices of urban farming within the distant or more recent past in this country. ${ }^{9}$

However, it is not that modern proponents of urban agriculture are simply not leaping over disciplinary fences to look at existing historical literature; the historical literature is largely nonexistent. U.S. urban histories generally treat agriculture as something that happened in fledgling cities in the colonial era and perhaps lingered for a bit in the times of the early Republic. Within the framework of mercantile and then industrial capitalism, increasing density, real estate speculation, and development pressures made urban land too expensive to be used for farming. And farming was superseded by what we have come to see as a natural evolution to more "city-like" or city-appropriate activities such as banking and manufacturing. Most of the time, the above processes are never even articulated: farming is simply dropped from the pages of the narrative. ${ }^{10}$

And yet there is evidence that farming, at least for some cities of the Northeast, remained an important part of their communities well into the twentieth century, although agriculture's persistent place in such cities largely remains to be documented. ${ }^{11}$ In perhaps the only book-length historical treatment of farming practiced in a major city, Mark Linder and Lawrence Zacharias show that agriculture, at least in Brooklyn, New York, has a history that goes far beyond the colonial and pre-industrial epochs. ${ }^{12}$ City farming flourished and intertwined with other activities even within increasingly dense urban surroundings, sometimes aided by that very density. Moreover, the decline of this agriculture was not a graceful and natural fading away of an obsolete land use; rather, it was the product of both the largely unfettered marketplace and a series of acts of commission and omission-government decisions and policies that framed what constituted "appropriate" uses of city land.

It is surely no coincidence that a reconsideration of the history of farming and subsistence gardening in cities is coming up at a time when many U.S. urban areas are experiencing an identity crisis and urban history a teleological one. Industry and density are no longer the apotheosis of urban life, and the next chapter of development in many cities is unclear, as is the future 
narrative arc for the overall story of U.S. cities. As activists and historians consider whither our cities are going, they are, for the most part, overlooking an opportunity that is worthwhile for several reasons. A consideration of past city farming practices adds a missing narrative strand to urban history while helping to challenge the "inevitabilist" model of urbanization, opening up alternative possibilities for city development. ${ }^{13}$ It is worth asking, as Linder and Zacharias do in their study of Brooklyn, "exactly how did a major city embrace, enclose, and finally obliterate its surrounding farms?" 14 Chronicling past urban farming practices can also provide useful models and cautionary tales for those currently engaging in or organizing formalized food production in U.S. cities. Probing this history both illuminates why our cities have followed certain models for development rather than others and what philosophical and logistical obstacles may currently lie in the path of incorporating food production back into cities.

This piece proposes to do three things: to address the reasons that the enduring existence of farming in cities has largely been missing from the historical record and erased from public memory, slipping into the cracks within and between various historical sub-disciplines; to show the ways in which these sub-disciplines' recent development has even so provided some of the needed documentary information and conceptual scaffolding that allows us to ask useful questions about historical urban farming; and to explore how a consideration of food production can add new dimensions to urban history, using as a case study my own nascent work on agriculture in Waterbury, Connecticut, in the late nineteenth through the late twentieth century. I will look specifically at three sub-disciplines: urban development history, agricultural history, and immigrant history.

My definition of urban agriculture takes some elements from both of the definitions cited on the first page of this piece and adds some other elements. Here, I examine food-raising activities taking place entirely within city boundaries but in areas that in their appearance and location range along a spectrum from the heavily urbanized to the arguably peri-urban. I believe that this municipal land-use range may have been more normal within developing nineteenth-century and early- to mid-twentieth-century cities than is generally recognized. Part of my goal here is to erase the sometimes false geographic dichotomy between what is a city and what is its hinterland. I also question the boundaries between farming, market gardening, and subsistence food-raised strategies, arguing that they too have taken place along a continuum within cities and can all be categorized as part of urban agriculture. Finally, included within this definition are a network of other professions closely related to the raising of city food and encompassing food processing and marketing, suggesting that food was a robust economic sector within cities like Waterbury with its butchers, produce wholesalers, grain, feed, and seed dealers and a host of others who relied on food producers for their livelihood. This food was produced for both local consumption and for markets beyond the city; however, it is the dynamic of production and consumption within the city that I am considering within this essay.

\section{Urban Development History}

What is regrettable is that professionals in urban landscape, ecology, and design are not including urban agriculture into their catalogues of urban assets. It is as though farming is the invisible ecology of our cities.

—Charles W. Lesher Jr. (Urban Agriculture: A Literature Review) $)^{15}$

One of the places where city farming could be more integrally discussed is in the history of urban development. However, one of the reasons that this area is neglected is embedded in the very ways the field of urban history is bounded. In his discussion of the overlooked importance of the urban 
within environmental history, for example, Martin Melosi quotes urban history pioneer Roy Lubove's definition of the field as "the process of city-building over time."16 Urban history is often framed that way and thus agriculture is filtered out as merely residual and irrelevant to the citybuilding process. Other dominant ways of telling the story of U.S. cities such as by changes in modes of production - from agriculture to commerce to industry - also must ignore farming past the early period of settlement. ${ }^{17}$ Both scholarly and popular narratives concerning Waterbury follow this modernization template. Popular belief, as expressed by one writer for Waterbury's 1965 city directory is that "the rugged terrain of Waterbury was not conducive to farming and as a result as early as 1750 Waterbury residents turned to manufacturing." 18 Most chroniclers of Waterbury history applaud the "Yankee ingenuity" that made the city an early hub of manufacturing and eventually the brass capital of the world, without considering the city's other economic sectors. ${ }^{19}$

However, if we go back to 1978 and Theodore Hershberg's famous call to not merely study "urban as site," but rather "urban as process," meaning "the dynamic modeling of the interrelationships among environment, behavior, and group experience," urban agriculture and its disappearance can be more fruitfully discussed. ${ }^{20}$ Linder and Zacharias's book on Brooklyn, Of Cabbages and Kings County has a subtitle that suggests this approach: Agriculture and the Formation of Modern Brooklyn. The authors assert that an active process of "deagriculturalization," which systematically removed farming from increasingly dense urban areas, was an integral part of the shaping of this city and later the borough it became from 1898 onward. ${ }^{21}$

Popular attitudes about appropriate land uses in densifying cities, supported by land speculators and city and state governments, were codified into laws that intentionally or unintentionally scrubbed out local food production. Struggles over whether or not, and on what terms, food production would take place in cities were integral to the process of city building in ways that have not been adequately explored. Within this mostly untold story, those who raised food worked for decades to hold onto their practices and to adapt them to changing environments. ${ }^{22}$ In this way, food growers were not all that different from those who struggled to maintain older traditions of craft work and resist deskilling during the nineteenth and early twentieth century, or those who fought to preserve their neighborhoods from the urban renewal or highway-building bulldozers of the later twentieth century. It is just that certain stories of struggle and loss, of physical erasure from the landscape, have been recognized and told, and others have not. The question is, why not?

Linder and Zacharias have suggested that scholarly and popular historical amnesia about urban farming - most people even in the areas where farms used to be are completely unaware of this past - is in part the result of the logic of a capitalist marketplace that citizens and scholars alike unquestioningly accept. In a country where urban development is largely driven by the private sector, the "law of higher commercial use" has dictated that as cities populate and urban land gets more expensive, uses of that land must be increasingly profitable for developers to invest in it and for cities to receive tax revenue. ${ }^{23}$ An "inevitabilist" historical progress narrative has unwittingly abetted capitalist development. So have cities' policies, especially by omission. By allowing certain "unprofitable" land uses to be protected - cemeteries and parks, for example - but not shielding farms from excessive taxation or development pressures, cities have made a choice to allow agriculture to disappear. ${ }^{24}$ Only in recent decades have these policies been reconsidered by state and city governments now working to manage sprawl while preserving green space and newly encouraging working farms. The logic behind mass-produced cheap food no longer seems so inevitable as municipalities seek economic revitalization and locally sourced, healthier food without the vulnerability and environmental impact involved in trucking in industrially farmed produce from thousands of miles away.

But there are other ways in which cities have more actively framed or legislated food production activities out of their boundaries. Scholars who seek to aid the cause of modern urban agriculture are often woefully unaware that farming might have been vigorously removed from cities 
in the past, although, as Lesher observes, "[b]y understanding how urban agriculture was planned out of our cities to serve certain contemporary ideals, a better understanding can be reached of how urban agriculture can be planned back into the urban context to serve new needs." ${ }^{25}$ For example, Kate Voigt mentions the imposition of local zoning codes in many municipalities in the early twentieth century but asserts in her example of Flint, Michigan, that "they likely were not written specifically to prohibit small-scale urban agriculture. . . Rather, they were written at a time when urban agriculture was not a common use of the land. .. The problem is that the laws on the books simply predate the city's new urban reality." 26

However, a few studies, including my work in progress, suggest that if we look back far enough to the origin of these codes, farming and other forms of food production were taking place in cities and that is precisely why laws existed first to regulate them and then to eradicate them. My current work on Waterbury, like Linder and Zacharias's in Brooklyn, suggests that, in fact, the process of urbanization was at times actively antagonistic to agriculture in ways that helped form the modern city. From the late nineteenth through the late twentieth century, in line with the national sanitary and health concerns of the Progressive Era, Waterbury passed a series of ordinances that increasingly restricted residents' ability to raise their own food. After Waterbury's Department of Health was founded in 1886, for example, the city got ever-stricter regarding inspection and handling of milk and food produced or sold in the city. ${ }^{27}$ By 1902, city ordinances specified that all households with farm animals had to pen and get annual city licenses for them. ${ }^{28}$ Those who had such animals were required to dispose of manure in a way that did not constitute a nuisance to their neighbors, and could have permits revoked on the basis of improper disposal, smells, and, by 1912, undue noise ${ }^{29}$ By at least 1905 , the city had a building inspector who both granted permits for residents asking to construct barns and, along with the health inspectors, increasingly waged war on residents trying to raise chickens and other livestock in small yards and even inner-city tenement apartments. ${ }^{30}$ Even those who lived in private houses found it increasingly difficult to have farm animals, as the city passed stricter ordinances and finally made it illegal in the zoning codes of 1972 to have livestock on land parcels of less than one acre. ${ }^{31}$

The market-driven development policies that favored residential development over agriculture were thus bolstered by municipal laws as well as the state-codified food reforms that grew out of the concerns of the Progressive Era. In fact, the reformist zeal of the late nineteenth and early twentieth century that urban histories discuss as eradicating some of the worst housing conditions in cities also made it more difficult for people to raise their own food or for nearby farmers to supply it to them. Progressive Era reformers championed causes like pure milk, for example, unwittingly leading to a host of regulations and conditions for milk production that helped put small producers out of business. ${ }^{32}$ Waterbury had had dozens of small milk producers and vendors but increasingly strict bottling laws, followed by pasteurization requirements in 1941, whittled down their ranks. ${ }^{33}$

These laws and development pressures were abetted by an "urban normative" or "urban imaginary" that has long had a hold on most people's visions of what cities "should" look like and what they should do. ${ }^{34}$ Colasanti, Hamm, and Litjen's study of contemporary Detroiters' attitudes toward the re-agriculturalization of their city illustrates this point. In that quintessentially deindustrialized city, some residents resist the notion of re-greening the city with comments such as "this is an urban area city. I do not want to walk past a field of wildflowers." ${ }^{35}$ A participant in Detroit's modern urban farming believed that for many people in the city, such practices are "a sign that the city ... has died and it's going back to its native landscape." 36 United Nations researchers have found that people in other urban areas of the world also hold such views: "The common perception in Africa and Latin America is that urban agriculture is marginal, temporary, and archaic." 37

Here, too, an exploration of urban history is useful, for these viewpoints reflect longstanding anxieties about what is modern and what is not, what is urban and what is not, and how those 
anxieties have shaped urban policy. In Waterbury in the nineteenth and early twentieth century, for example, city officials contracted pig farmers to collect kitchen scraps from municipal households, one of many ways in which the lives of city farmers meshed well with the increasingly dense urban environment. This arrangement proved cheap and put needed cash into the pockets of these largely subsistence farmers. Nonetheless, city officials looked anxiously over their shoulders and worried that the practice was not modern enough. In his annual address to the city in 1912, Waterbury Mayor Francis T. Reeves acknowledged that although feeding Waterbury's garbage to pigs saved about $\$ 12,000$ a year while "our crematory, which cost more than $\$ 10,000$, is rapidly falling into ruin," he was concerned because

It seems to be the opinion of experts on hygiene and sanitation that this method of disposal is dangerous to the health of the people and ought not be adopted by any city the size of Waterbury. ... It is a fact ... that the method of feeding to swine is disappearing in cities of Waterbury's size and reduction incineration and cremation are taking its place. ${ }^{38}$

By the 1950s, the practice was ended and "modern" garbage collection began. Pig farmers still collected scraps from restaurants, produce stores, and bakeries but no longer got a cash infusion from the city. As of 1959, they were required to cook their gleanings into a mash that reached the boiling point to kill any malevolent organisms. ${ }^{39}$

Now, as sustainability becomes a watchword for our cities, experts studying urban life wonder if the pendulum has swung too far. Some urban agriculture researchers assert that modern sanitation systems have simply moved waste around while squandering recycling opportunities. ${ }^{40}$ Linder and Zacharias go as far as to suggest that managing agriculturally linked urban problems such as manure disposal were what led to city policies such as sanitation and thus are intrinsically bound up with early urban planning. ${ }^{41}$ Their contention implies that if we are to re-envision our cities and their relationship to agriculture, we will need to tease apart the historical relationship between local food production and urban development.

The power of the "urban normative" also shapes how we view possible urban food production strategies of the present and how or even if we are aware of their past. Writing about subsistence gardening in Columbus in the first four decades of the twentieth century, geographer Sarah Moore suggests that residents' unofficial food production has been written out of urban history because of an "urban normative," that saw subsistence food production as superfluous to urban life and emblematic of the very underdevelopment and "backwardness" that both modern Detroiters and turn of the century Waterbury officials worried about. In this view, partly shaped by the Chicago School of urban studies, subsistence gardens mainly existed during times of crisis and in the interstices of "modern" urban life. Moore connects the struggle over the practice and meaning of these subsistence gardens of the past with modern struggles over urban gardening in cities such as New York, studied by scholars within the "right to the city" framework developed by social geographers. ${ }^{42}$

This modernist urban normative framework has several consequences for both the study of the urban agricultural past and for urban food production in the present. If urban gardens that raise food, or city food production in general, are superfluous to the larger purpose of the city and the development of land within capitalism, then such gardens are necessarily temporary and always under threat when the crisis is over and the land they are on becomes valuable again. Rather than being part of alternative development strategies, Moore argues, such landscapes have become expendable, subsumed by the for-profit strategies of developers. And indeed, most portraits of historic community food-raising projects focus on officially sponsored gardening efforts during times of crisis such as the World Wars or the Great Depression. ${ }^{43}$ But, as Moore shows in the largely black American Addition neighborhood of Columbus, people had actually raised their own food, unsponsored, since they had arrived in the city in the early 1900s, "in backyards and on vacant lots and later . . larger communal plots." 44 
What Moore finds in an African American neighborhood in Columbus was true of many areas of Waterbury. Oral histories show that many people raised their own food in an ongoing, informal way - that is, not under the auspices of an organization or government entity during a circumscribed period of crisis. The city also had its share of Liberty Gardens and Victory Gardens during World Wars I and II, respectively, as well as Department of Education-sponsored gardens and other short-lived initiatives, but such officialized gardening efforts have been much better documented in the historical literature than the informal variety. ${ }^{45}$ Such non-official food production in the past, of course, raises the question of whether or not the contemporary urban normative can be broadened to include subsistence food strategies as an accepted part of daily life. The presence of a variety of food-raising strategies in Waterbury's past raises other questions that need to be explored in relation to this city and others - is the distinction between farms, gardens, and other food production clear-cut or does it take place more along a continuum? What is the difference, for example, between a farmer and a gardener, a subsistence farmer, and a market gardener? Oral history testimony shows that people defined themselves and their activities in a variety of ways that push the boundaries of such classifications. Some called themselves farmers; others saw themselves as gardeners, although in some cases they were engaging in identical activities on parcels of land of similar sizes. Some sold the food they produced for cash while for others they were the basis of a subsistence lifestyle or a barter economy. ${ }^{46}$ Only when we fully explore these categories will we understand the role that food production has played, is playing, and can play in urban life.

There are other ways in which cities have supported or quashed food production practices that are useful to know both for the historical record and for those constructing municipal "food systems" in the present. In their paper "Farming Inside Cities: Entrepreneurial Urban Agriculture in the United States," Kaufman and Bailkey speak of "a wobbly three-legged stool" whose components need to be strengthened for agriculture to flourish in cities. The first leg is "urban vacant land" and the second, "entrepreneurial urban agriculture" or the collection of people and groups who advocate for and put into practice city farming projects. The third, and most relevant one for this discussion, is "the local institutional climate," which includes whether or not the local government is supportive of urban agriculture and has policies and laws that demonstrate that support. ${ }^{47}$

As an all-too-slender literature on farmers' markets shows, many cities used to provide at least some institutional support for local growers. Farmers' markets surged around the urban United States in the World War I era, a time of inflationary food prices. ${ }^{48}$ Waterbury's farmers' market opened in 1917 and was initially sponsored by the Chamber of Commerce but on land provided by the city, which later created ordinances to manage the market. ${ }^{49}$ Many of the growers were from inside the city itself. The market lasted until at least the 1960s, when the land it was on was taken over by the state as part of the building of Interstate 84 . But the farmers' market was not the only institutional support Waterbury, and likely other cities, gave to local farmers and food production, that later died for reasons that bear investigation. ${ }^{50}$

For example, most cities and towns had "town farms," places where poor people, petty criminals, and the mentally challenged were essentially warehoused and put to work. In Waterbury's case, the local government initially contracted with local farmers in the 1820 s to provide room and board for these "intractables" in exchange for work. By 1839, the city had bought a farm that it continued to manage for several decades. Brookside, as it became known later in the century, both produced food and bought from local farmers, farm supply stores, and city meat and produce merchants. ${ }^{51}$ Waterbury also had a municipal slaughterhouse and possibly other institutions supportive of farming that are yet to be discovered and might shed light both on ways in which municipalities have nurtured and can nurture urban agriculture and the consequences to this sector when such support, once given, is withdrawn. ${ }^{52}$

But the story of farming in cities such as Waterbury can only be properly told by casting back to its pre-industrial origins and exploring both the continuities of and changes to such farming as cities became more dense and industrial. While urban farming is largely absent from agricultural history, the field provides models that help explain such farming, as the below section illustrates. 


\section{Agricultural History}

As Linder and Zacharias note in their Brooklyn history, it is important "to add a new dimension to agricultural history and urban history instead of perpetuating their disciplinary separation or mutual ignorance." ${ }^{53}$ It is true that agricultural history writing has almost exclusively focused on rural history, in which small towns are the largest places of settlement. New England agricultural history is also chronologically truncated, even for rural areas. Howard Russell's synthetic agricultural history of New England, published in 1976, is still the only one of its kind, and it ends its story in 1921, implying that farming largely ceased to exist in the region after that era. ${ }^{54}$

And yet much New England agricultural history written in the last few decades, regardless of its rural bias or chronological limits, has provided useful tools for looking at urban agriculture in the region. Recent New England agricultural historiography has first of all challenged the idea, common in traditional U.S. history narrative, that the region was an overall failure in farming that gave way to the better lands to its west as soon as settlement was possible in those newer areas. There are several reasons that this assumption of regional failure has had such traction; one in particular is particularly relevant here. As Brian Donahue has pointed out, historians have also often taken at face value the testimony of late-nineteenth- and early-twentieth-century journalists and agricultural scientists. These writers often lamented the overall population loss in rural areas of the Northeast without considering those who stayed behind and the continuities of their family, agricultural, and community lives. Agricultural scientists were also pushing for more modern cultivation methods, averring that New England soil was on its own too rocky or infertile for farming or that poor cultivation practices had stripped it of what few nutrients it had. ${ }^{55}$

Historians such as Hal Barron, Christopher Clark, Brian Donahue, J. Ritchie Garrison, and Richard W. Judd show, however, that farming continued in the region over centuries, based often on longstanding, careful stewardship by generations of the same families. ${ }^{56} \mathrm{New}$ England residents who left for the "west" in the post-colonial period often did so not chasing better soils but because there was not enough land to sustain ensuing generations of these farming families as their population expanded geometrically, much less to accommodate newer arrivals. However, much of the original farmland stayed in production. ${ }^{57}$

In fact, historians of rural New England show the remarkable resilience and persistence of New England farmers in the face of challenging soil and topography and constantly changing market conditions. These farmers continually revamped their production, jiggering their crop ratios or incorporating new types of livestock or plants to capitalize on new opportunities. In most cases (with the most conspicuous exception of tobacco farmers in the Connecticut River Valley starting in the mid-nineteenth century), these farmers had an extraordinarily diversified production in which no one crop predominated. They farmed more intensively over time but also intelligently, aware of the need for sustainable practices. They also creatively combined farming with a variety of other income-producing strategies including home production of hats or brooms, various artisan trades, mercantile pursuits, and even professional or civic occupations. ${ }^{58}$

Farms in New England generally became more productive over the course of the nineteenth century and into the twentieth. ${ }^{59}$ When they failed it was for a host of complex reasons, including the fact that their very productivity could lead to oversupply and falling prices. ${ }^{60}$ New England farmers also had to contend with a plethora of trends that weakened small agricultural operations everywhere. These included price undercutting or monopolistic practices by increasingly large, capital- and petroleum-intensive and industrialized food-producing firms on first a national and then a global level, concentration in sectors such as the dairy industry as a result of more stringent regulations and processing requirements, and technologies that undermined the value of local marketing, such as the post-Civil War development of refrigerated train cars, or the later development of refrigerated trucks, which allowed formerly delicate, more perishable products to travel longer distances. ${ }^{61}$ 
Rural New England studies give us a context for discussing the persistence of farming/farmers in the region's cities as well, as my case study demonstrates. Waterbury, in the western part of Connecticut, is not part of the Connecticut River Valley studied by several of these historians. Rather, it is more than twenty miles to the west of this watershed, part of what environmental historian Richard Judd characterizes as four New England topographies, each more westward from the sea and with its own set of challenges. Waterbury fits into the third of these topographies, "a range of unconsolidated upland hills and ridges back from the valleys." 62 Situated in the Naugatuck Valley in the foothills of the Berkshire Mountains, the city has several hills reaching sharply up to eight hundred or nine hundred feet.

Waterbury was founded in 1674 and was first a town, then a borough; it was incorporated as a city with its present boundaries in 1853. As all English settlements of the colonial era, it began with farming. However, the mills that had grown with the early settlement evolved into industry that took advantage of the relatively flat land on both sides of the Naugatuck River while harnessing the water power coming down the "gentle, relatively regular slope tilting down off the Appalachian Plateau." 63 By the 1870s, Waterbury had begun to mature into its position as America's "Brass City." By that time, dozens of factories roared and smoked day and night; the population had swelled from 10,806 in 1870 to 17,806 in 1880 , continuing to grow until it reached over 100,000 in $1930 .{ }^{64}$

And yet behind this multi-factory clamor and the boosterish hoopla surrounding Waterbury's spectacular transformation lay this other sector, partly continuous with the past and partly intertwined with this recently acquired industrialism - the sector of food producers and those who worked in related occupations. Research through census records and city directories of the 18701880 period show close to two hundred people officially listed as farmers. ${ }^{65}$ Maps reveal that most of their farms were located in the hilly city land that rose sharply just past the immediate river bank terrain abutting the Naugatuck and Mad Rivers. While those river banks were virtually monopolized by industry, close by as the elevations rose were farms that grew produce and had animals grazing on their upper reaches. Farming persisted within the city of Waterbury, interspersed with or in close proximity to both its industry and its growing neighborhoods of factory workers, as maps and city directories of the late nineteenth and early twentieth century attest. ${ }^{66}$ Many of the city's farms exhibited the same continuities of ownership chronicled by historians of rural New England agriculture: farmers were descendants of the original seventeenth-century proprietors of the town or its parent colony of Farmington, or had come by the early post-Revolutionary War era. ${ }^{67} \mathrm{~A}$ surprising number were still either full-time farmers or plied closely related trades that varied with the possibilities of the time period. The Pierponts, for example, were Huguenots who arrived in Waterbury, by way of England and then New Haven, around the time of the American Revolution. From then and through the nineteenth century, they raised beef and dairy cattle and were butchers, ambulatory meat peddlers, and meat market owners, later converting entirely to dairy farming, as many in the Northeast did with the advent of the virtually monopolistic Chicago meat-packing industry. ${ }^{68}$ Several Pierpont land parcels can be found on the 1874 map of Waterbury and they are well represented in the 1870 and 1880 censuses. The 1870 census, for example, shows Enos Pierpont with four hundred acres, a giant tract of land by the standards of the time and place. His nephew Austin B. Pierpont had in 1880 a farm of some 115 acres, including ten tilled acres and thirty in meadows, pastures, and orchards, and twenty-five in woodlands. He had two horses, two working oxen, eleven "milch cows," and several other cows and calves. In 1879, he had sold some six thousand gallons of milk to factories to make butter and cheese and had 175 pounds of butter and 150 pounds of cheese made on his farm. He had fifty chickens from which he got three hundred eggs. He grew "Indian corn," oats, and rye and produced twenty pounds of maple sugar, two hundred bushels of potatoes, 150 bushels of apples, and five cords of wood. ${ }^{69}$ Most Waterbury farmers had 250 acres or less of "improved" land, but many of their rural counterparts had even less to work with. ${ }^{70}$ These city farmers' allocation and 
use of different types of land and typical crop spreads were in line with these rural counterparts, and indeed, with Austin Pierpont's farm, if usually on a smaller scale.

Census and city directory tallies of Waterbury farmers do not take into account those who were listed under other professions but still raised food, a category that recent New England agricultural historiography has alerted us to. In fact, a number of farmers were simultaneously involved with agriculture and industry, supporting Richard Judd's assertion that "early industrialization was not funded by urban merchants but by farmers seeking outlets for their savings." 71 Judd's larger point that "farms and factories evolved in tandem as partners" is illustrated by the story of Timothy Porter, a descendant of one of Waterbury's earliest families. ${ }^{72} \mathrm{~A}$ biographer saw no contradiction in describing him as "one of the prominent and successful farmers and manufacturers of Waterbury." By the end of his busy life, Porter had served as a church deacon, taught school, run a carding machine and a brickmaking business, and, in 1845, established a brass mill on his property in the center of Waterbury, very likely while still continuing to grow food. ${ }^{73}$

New England agricultural historians also refute the notion of strict periodization of farming versus industry, or of a strict dichotomy between subsistence farming and market-oriented farming. As Judd points out, "[h]istorians typically think in neat, linear terms - first an agricultural frontier and then an industrial era" but of course change happens more slowly than that, in "slow accretions over time," as J. Ritchie Garrison observes in his study of farming in Franklin County, Massachusetts, noting "the older farm communities did not simply disappear because of industrial growth." ${ }^{\prime 4}$ These historians compel us to look at the symbiotic relationship between industrial and agricultural areas.

For example, agricultural historians have documented how farmers tailored their strategies to accommodate the increasing population of nearby cities. Brian Donahue describes farmers in Concord, Massachusetts, adapting and readapting their food production strategies throughout the nineteenth century, increasingly orienting their output toward the densifying Boston population and its growing demands for meat, fodder for urban horses, firewood, milk, and eating apples rather than the traditional cider apples. ${ }^{75}$ In her study of milk production and consumption, E. Melanie DuPuis goes as far as to say that the demands of the urban populace increasingly shaped the national perception of farmers and their role within the U.S. economic system, and that "fresh milk as an essential form of daily, year-round nutrition came about only with the rise of the city." 76 In fact, production of perishables such as dairy products and fruit and vegetables at least close to, if not in cities, swelled as urbanization increased and has lasted into our times. ${ }^{77}$

This linkage between city and nearby country was not just about food and it went in both directions. In The Horse in the City, for example, Clay McShane and Joel Tarr show the importance of hinterland areas in raising horses for cities that needed them for their (literal) horsepower and for transportation in the city of the pre-automobile era. These urban horses in turn produced manure, which was a valuable commodity brought back to area farms. ${ }^{78}$ As William Cronon argues at the end of his pathbreaking city-and-hinterlands study of Chicago, "how a city's life and markets connect to the countryside around it — can be asked of every urban place that has ever existed, no matter how large or small." 79

Cities such as Waterbury, however, force a reconsideration of the opposition between urban and rural, city and hinterland, or at least force us to reconsider the boundaries and in some cases move them much further inward. For Waterbury for a long time contained much of its hinterland within city limits, with symbiotic relationships between farmers and their customers, food producers and food processors, and a host of other relationships, all in the city itself. Of course Waterbury, in Cronon's formulation of the hierarchy of cities, was a "lower-order town," before 1930 one of "the 326 cities with populations less than 100,000 but more than 10,000 " so by definition its regional reach would be smaller than Chicago's, at least as far as food production and processing. ${ }^{80}$ Such smaller cities may indeed have had more geographical interpenetration between industry and agriculture than larger urban areas and are worthy of study in their own right. 
In Waterbury, the Pierponts' meat wagons and later their milk trucks plied the dense inner-city neighborhoods where first the Irish factory workers lived, then the Eastern and Southern Europeans of the later immigration stream. ${ }^{81}$ Some of these immigrants themselves began agricultural operations much later than farms were "supposed" to be started in industrial cities. In the late nineteenth century, for example, Danish-born Hans Rasmussen and his brother-in-law established themselves as dairy farmers and milk peddlers in Waterbury's Town Plot neighborhood, and another brother started raising flowers in a greenhouse, one of several within city limits. ${ }^{82}$ In the summer and fall, Hans' son Ernest later wrote, the family would load "acres of cabbages" on their wagon and sell them in the inner city "by display or by knocking on the doors of the Irish and Lithuanian folks." 83

Waterbury farmers ran or utilized local slaughterhouses or pasteurization operations when pasteurizing milk became mandatory in the early twentieth century. The city also grew to have a robust farm supply and food processing sector in which live chicken stores, farm implement and feed merchants, wholesale fruit and vegetable peddlers, and storefront produce vendors all had a part. ${ }^{84}$

Farmers also took advantage of their city location as a source for resources, both material and human, engaging in what in our times is called recycling. Vito Becce, an Italian immigrant who came to the United States in 1906, used his earnings from mining and industrial work to start a pig farm seven years later. Becce got sawdust and shavings from local lumber mills to use as insulation in the barns and bedding for the pigs, and scoured the city for old telephone poles and billboards to use for various farm building projects. When he needed labor for his farm, Becce typically hired local transients, hard-drinking men for whom short-term employment was the only option - the kind of people who now would be considered unemployable and probably be homeless ${ }^{85}$ In many ways still to be explored, city farms complemented other urban activities as the area developed.

\section{Immigrant History}

Not all of the people pouring into the United States in the late nineteenth and early twentieth centuries came to take industrial jobs or to live in its sprawling cities. Many headed west, seeking work on the farms and ranches there.

—Leonard Dinnerstein, Roger L. Nichols, and David M. Reimers (Natives and Strangers: A History of Ethnic Americans) $)^{86}$

Urban immigrant and ethnic history has, of course, been a major area of study for scholars. Historian Royden Loewen points out, though, that for both Canada and the United States, "the field of rural ethnic history is immensely rich" as well, and has been somewhat neglected. ${ }^{87}$ Immigrant farming history has, for the most part, been chronicled for the Midwest and further westward, leaving even rural New England out of the story. ${ }^{88}$ And yet a chronicler of Connecticut agriculture claims that

By 1930, 58\% of the farmers in Connecticut were of foreign birth and in 1940, just before the start of WW II, two out of every three farmers had immigrated to Connecticut. In 1942 it was reported that, among all the states, Connecticut had the highest percentage of foreign born farmers. ${ }^{89}$

Even a cursory look at other urban, peri-urban, and rural areas of Connecticut, Massachusetts, and other parts of the Northeast corroborates this trend. ${ }^{90}$ The history of both rural and urban immigrant farming in the region has been mostly buried, however, by the dominant narrative of immigrants in this area as factory laborers in cities.

The stories of farmers in Waterbury from the late nineteenth through the late twentieth century show that agriculture in the city had by that time become the province mainly of immigrants and 
their direct descendants. Hans Rasmussen and Vito Becce, mentioned in the previous section of this piece, were emblematic of this new breed of immigrant farmers. Oral histories, memoirs, city directories, and other sources reveal immigrant endeavors in the cultivation and processing of livestock and crops. Waterbury immigrant farmer stories belie the stereotypical peasant-to-industrial worker trajectory as well as the modernization theories that have been recently challenged by contemporary agricultural historians such as Royden Loewen. ${ }^{91}$ Some of the immigrants, like Rasmussen and Becce, came from farming families back in their homelands, and worked industrial and construction jobs just until they could buy farmland. Others continued factory and other employment simultaneously with the cultivation of food. Still others went from factory work to a first-time pursuit of occupations most would associate with rural areas. John and Candida DeLaurentis, for example, who were actually the children of Italian immigrants, went from brass factory work to raising chickens on a tiny urban parcel starting in $1945 . .^{92}$

One reason that immigrant farmers have been overlooked may have to do with the prevalence of nativism during the period in question, and here again, we must resist taking contemporary writers' words at face value. When late-nineteenth- and early-twentieth-century agricultural experts and journalists bemoaned the attrition of New Englanders from farming careers, they were referring implicitly or explicitly to white Protestants of older immigrant stock. It was not, entirely, that farming was disappearing; it was that the prototypical Yankee farmer was being supplanted by another kind. At the 1898 annual meeting of the Connecticut Dairyman's Association in Hartford, for example, Wisconsin dairy farmer W.D. Hoard warned his audience about "the passing of the American farmer" and that "the farm peasantry of Europe are pouring in and those people are taking our farms as quickly as the American sons are abandoning them." $" 93$ Twenty-two years later, the Hartford Courant would complain bitterly of the exodus of native young men from the farms to more lucrative factory work. The newspaper claimed that high prices for labor, fertilizer, and other inputs in the wake of World War I were driving the Yankee farmer out of business, where he was replaced by "foreigners, with large families in which the women and children work in the field." 94

Immigrant farmers are also largely invisible when it comes to more official farm-related activities, mostly absent from records of agricultural association meetings or county fairs. Whereas the Pierponts, for example, were active in a number of Connecticut agricultural organizations and routinely won prizes for cows or apples at fairs, farmers such as the Rasmussens and Becces are missing from records of such institutionalized agricultural activities. ${ }^{95}$ It is possible that immigrant farmers were ostracized or felt unwelcome within such groups, as Hoard's 1898 speech for the Connecticut Dairymen's Association would suggest, or that as Loewen notes, they were "intentionally working outside of the imposed discourse" of a market-oriented scientific farming that was not aimed at them. ${ }^{96}$ Judd implies an opposition between "gentleman farmers" advocating more scientific agricultural methods and those who ran subsistence farms growing a wide variety of crops with a more tentative relationship to the marketplace, which included the growing ranks of immigrant farmers. ${ }^{97}$

Much more work needs to be done on immigrant farming in cities such as Waterbury. Archival research on property records, for example, will show patterns of land ownership and land transfer and the increasing role immigrants played in urban agriculture. The archives of the National Grange of the Order of Patrons of Husbandry and other agricultural associations will also have a story to tell, whether it is of the presence or absence of immigrant urban farmers. Oral histories collected in Waterbury thus far, however, indicate that immigration and ethnicity could be a significant factor in how farming and food production and delivery were carried out. Members of Waterbury's Bosse family, dairy farmers from French Canada, remember having a virtual monopoly on delivery to their compatriots in the tenement districts of the city. ${ }^{98}$ Almost all the garbagecollecting pig farmers of the late nineteenth and early to mid-twentieth century appear to have been Italians or Italian Americans. ${ }^{99}$ Some farmers clustered geographically by ethnicity-a 
grouping of German farmers and their immediate descendants could be found in Waterbury's Bucks Hill neighborhood from the late nineteenth until the mid-twentieth century. ${ }^{100}$

\section{Conclusion}

By the late twentieth century, farming and local food production, processing, and marketing had largely disappeared from cities such as Waterbury. Farming within cities was of course subject to the pressures that ultimately affected agriculture outside the cities: the rise of capital-intensive, petroleum- and technology-driven farming that undercut the prices and proximity advantages of local food production, the rising value of land for housing and other building projects, and residential neighbors resistant to the smells and sounds of nearby agriculture. It is likely that a combination of these general threats to small family farming and specifically urban pressures and opportunities decimated - though never completely killed - agriculture in small industrial cities such as Waterbury. The Rasmussens, for example, began to develop their land into house lots after World War I, when farm labor was scarce and immigrants and their children were beginning to look beyond their tenement apartments for more bucolic living situations. The Pierponts ran their dairy farm until the 1970s, when the city took over their land by eminent domain to build a public elementary, middle, and high school complex. The Becces continued their hog production operation into the 1980s and their hay production until recently. In the meantime, however, small horse properties and poultry and sheep operations continue to emerge within Waterbury's borders.

As the paradigm continues to shift from the twentieth-century gospel of efficiency-for both cities and farming - to a greater awareness of the multiple social and economic benefits of local food production, cities like Waterbury may, in fact, "reagriculturize." More robust studies of an urban agricultural past will help to inform this process while enriching the field of urban history.

\section{Declaration of Conflicting Interests}

The author(s) declared no potential conflicts of interest with respect to the research, authorship, and/or publication of this article.

\section{Funding}

The author(s) received no financial support for the research, authorship, and/or publication of this article.

\section{Notes}

1. Marc Linder and Lawrence S. Zacharias, Of Cabbages and Kings County: Agriculture and the Formation of Modern Brooklyn (Iowa City: University of Iowa Press, 1999), 2.

2. Kathryn J. A. Colasanti, Michael W. Hamm, and Charlotte M. Litjens, "The City as an "Agricultural Powerhouse?' Perspectives on Expanding Agriculture from Detroit, Michigan,” Urban Geography 33, no. 3 (2012): 348-69.

3. G. Shabbir Cheema, Jac Smit, Annu Ratta, and Joe Nasr, Urban Agriculture: Food, Jobs, and Sustainable Cities (New York: United Nations Development Programme, 1996), 3.

4. Charles W. Lesher Jr., Urban Agriculture: A Literature Review (Beltsville: United States Department of Agriculture, 2006), 69.

5. Jerry Kaufman and Martin Bailkey, "Farming Inside Cities: Entrepreneurial Urban Agriculture in the United States" (working paper, Lincoln Institute of Land Policy, Cambridge, MA, 2000), abstract, n.p.

6. Colasanti, Hamm, and Litjens, "City as an "Agricultural Powerhouse," "348, write about some of the stakeholders currently discussing and grappling with urban agriculture in the United States, "including planners, architects, and public health professionals."

7. Kaufman and Bailkey, "Farming Inside Cities," abstract and 5-6. 
8. Kate A. Voigt, "Pigs in the Backyard or the Barnyard: Removing Zoning Impediments to Urban Agriculture," Environmental Affairs Law Review 38, no. 2 (2011): 537-66.

9. See Jac Smit, Joe Rasr, and Annu Ratta, "Urban Agriculture Yesterday and Today," in Urban Agriculture: Food, Jobs, and Sustainable Cities, 2001 ed. (Published with permission from the United Nations Development Programme [UNDP]), 9, which suggests that it is time for "a South-North knowledge flow to complement the North-South flow that has dominated agricultural exchanges over the past couple of centuries." Although these authors mention English allotments and Paris marais as examples of European urban food-raising continuities, historical agriculture in the urban United States is discussed on pp. 21-22 in an anecdotal and disconnected way. Lesher, Urban Agriculture, notes on p. 35 and at other points throughout his work that much of the literature on urban farming is developing nation based. Most of these reports are policy based, pragmatic, and prescriptive in nature. Lesher, for example, cites on p. 19 the UNDP 1996 report as saying that "by the year $2025,80 \%$ of the world will live in cities" and that the recent rural to urban migrants of the poorer countries are likely to be successful in urban agriculture because "this population is less removed from an agricultural tradition than in developed societies." But the authors do not examine the reasons their U.S. evidence is so episodic or why farming in our cities ceased or diminished. Jac Smit, Joe Rasr, and Annu Ratta, "Urban Agriculture Yesterday and Today," in Urban Agriculture: Food, Jobs, and Sustainable Cities (2001 edition, published with permission from the United Nations Development Programme), 1-31

10. See, for example, Sam Bass Warner, The Urban Wilderness: A History of the American City (1972; repr., Berkeley: University of California Press, 1995), where farming is mentioned in the first two chapters mainly in terms of land allotments and early planning system, and is only mentioned again briefly in relation to westward expansion and the rural backgrounds of immigrants coming to cities; Eric H. Monkkonen, America Becomes Urban: The Development of US Cities and Towns, 1780-1980 (Berkeley: University of California Press, 1988), where farming/farmers are mentioned for colonial towns on pp. 60 and 62 but then not mentioned again except as markets for products produced in cities or as anti-urban political forces; David R. Goldfield and Blaine A. Brownell, Urban America: A History, 2nd ed. (Boston: Houghton Mifflin, 1990), where agriculture is briefly mentioned in relation to colonial settlements especially in the South and in terms of crops contributing to an overall economy with a brief mention (pp. 58-59) of Benjamin Franklin's and Thomas Jefferson's vision of cities' identities being bound up with agriculture; Howard P. Chudacoff and Judith E. Smith, The Evolution of American Urban Society, 6th ed. (Upper Saddle River: Pearson Education, 2005), which in its first pages mentions that early on "colonial towns bred merchants and tradesmen" and that "each city began to cultivate its own commercial hinterland" (p. 7) and also mentions (p. 10) cows and pigs roaming early urban streets, speaking about agricultural patterns mainly as economic growth engines for cities or as symptoms of their growing pains.

11. Thomas A. Lyson, Civic Agriculture: Reconnecting Farm, Food, and Community (Medford, MA: Tufts University Press, 2004), 4-5; Linder and Zacharias, Of Cabbages, 6, 38.

12. Linder and Zacharias, Of Cabbages.

13. Ibid., 13, 296.

14. Ibid., 2.

15. Lesher, Urban Agriculture, 62.

16. Martin Melosi, "The Place of the City in Environmental History," Environmental History Review 17, no. 1 (Spring 1993): 13: 1-23.

17. See, for example, Theodore Hershberg's discussion on this particular frame in "The New Urban History," Journal of Urban History 5, no. 1 (1978): 3-40, especially pp. 11-14.

18. Price \& Lee's Waterbury Directory 1963 (New Haven: Price and Lee, 1963), 12.

19. Linder and Zacharias, Of Cabbages, 339, footnote 7. Accounts of Waterbury and other towns in the Naugatuck Valley, Connecticut's history also follow this evolutionary model, for example in Jeremy Brecher, Banded Together: Economic Democratization in the Brass Valley (Urbana: University of Illinois Press, 2011), 3: "Farm villages became mill villages and eventually industrial towns and cities." While this is substantially true, it is not the whole story.

20. Hershberg, "New Urban History," 33.

21. Linder and Zacharias, Of Cabbages, 6.

22. Ibid., show this struggle in Brooklyn, especially in Chapter 7, 156-84. 
23. Linder and Zacharias, Of Cabbages, 10.

24. Ibid., 290-95.

25. Lesher, Urban Agriculture, $62-63$.

26. Voigt, "Pigs in the Backyard or the Barnyard," 546, 549.

27. Municipal Register of the City of Waterbury for the Year 1886 (Waterbury: Malone and Cooley, 1887), 14-15.

28. Charter and Ordinances of the City of Waterbury, Connecticut (Waterbury: Mattatuck Press, 1902), 246-50.

29. The Compiled Charter and Ordinances of the City of Waterbury (Waterbury: Press of the Waterbury Evening Democrat, 1913), 378.

30. "Report of the Health Officer for the Year 1912," in Municipal Register of the City of Waterbury for the Year 1912 (Waterbury: Press of the Waterbury Evening Democrat, 1913), 5-7.

31. Zoning Ordinance Waterbury Connecticut, November 1, 1971, Amended and Adopted by the Zoning Commission, April 27, 1972, Effective June 1, 1972, 69. Still, impressive numbers of Waterbury residents kept petitioning the city for the right to build barns and to keep animals, at least through the 1920 s and probably beyond. Building inspectors are still in the twenty-first century grappling with residents, often recent immigrants, who keep farm animals without a license in apartment buildings or houses with small yards.

32. E. Melanie DuPuis, Nature's Perfect Food: How Milk Became America's Drink (New York: New York University Press, 2002), 88.

33. Ordinances of the City of Waterbury (Waterbury: The Standard Printing Company, 1926), 320-24; Ordinances of the City of Waterbury (Waterbury: The Heminway Press, 1944), 212. Silas Bronson Library, Waterbury, CT.

34. Colasanti, Hamm, and Litjens, "City as an 'Agricultural Powerhouse'," 362.

35. Ibid., 356-57.

36. Ibid., 357.

37. Lesher, Urban Agriculture, 36.

38. Municipal Register of the City of Waterbury for the Year 1912, 21-22.

39. "General Statutes of Connecticut, Revised to January 1, 2013," vol. 8, title 22, "Agriculture, Domestic Animals," chapter 433, section 22-320b, "Garbage to be heated to boiling point," https://www.cga. ct.gov/current/pub/titles.htm and then click on first link "General Statutes of Connecticut-Titles"

40. Smit, Rasr, and Ratta, "Urban Agriculture Yesterday and Today," 8, assert that "Over the past century ... the trend has been to minimize the use of urban waste by introducing modern sanitation systems. The accepted ideal has become 'the city beautiful' and 'the city healthful' . . Sanitation systems, combined with changes in technologies, helped to clean up the urban environment. Nevertheless, the approach has created problems in both industrial and developing countries. The systems are unsustainable because they shift and dispose of increasing volumes of waste from one location to another within the urban ecosystem or outside, and the infrastructure often fails."

41. Linder and Zacharias, Of Cabbages, 44.

42. Sarah Moore, "Forgotten Roots of the Green City: Subsistence Gardening in Columbus, Ohio, 19001940," Urban Geography 27, no. 2 (2006): 174-92.

43. Thomas J. Bassett, "Reaping on the Margins: A Century of Community Gardening in America," Landscape: A Magazine of Human Geography 25, no. 2 (1981), 1-8; Laura Lawson, City Bountiful: A Century of Community Gardening in America (Berkeley: University of California Press, 2005); Char Miller, "In the Sweat of Our Brow: Citizenship in Domestic Practice During WW II-Victory Gardens," The Journal of American Culture 26, no. 3 (September 2003), 395-409.

44. Moore, "Forgotten Roots," 179.

45. See, for example, Bassett, "Reaping on the Margins"; Lawson, "City Bountiful"; and Miller, "In the Sweat of Our Brow."

46. Nick Coscia, for example, detailed how his family bartered produce with a variety of neighborhood residents and institutions to meet other family needs, interview with author, September 11, 2013, while Sam Gucciardi, whose family cultivated a tiny plot, called the family "farmers," probably because they sold their produce at a stand at the end of their driveway. Interview with author, September 20, 2013.

47. Kaufman and Bailkey, "Farming Inside Cities," 3, 7-8. 
48. Don Shakow, "The Municipal Farmer's Market as an Urban Service," Economic Geography 57, no. 1 (January 1981): 68-77; Jayson Daniel Otto, "Broadening the Concept of Civic Agriculture: The History of Civic Food Systems in Progressive Era Grand Rapids, Michigan" (Master's thesis, Michigan State University, 2011); Lyson, Civic Agriculture, 91-92.

49. "An Amendment to an Ordinance Entitled an Ordinance Relative to a Wholesale and Retail Market," in Ordinances of the City of Waterbury (Waterbury: The Standard Printing Company, 1926), 407.

50. New Haven's Mayor Richard Lee, nationally famous for jumping early on the urban renewal bandwagon, had been instrumental between the mid-1950s and mid-1960s in clearing out his city's longstanding produce market from its home across from the train station. Mayor Lee, looking to "modernize" his city, declared the market and its buildings "relics of a bygone age" and averred that "one can hardly imagine a less impressive entrance to a city." Within this new vision of a cleanedup New Haven, the previously logical link between produce markets and rail transportation hubs was now broken. Farmers' markets were to be viewed as part of the blight that was creeping over post-World War II cities, contributing little to the tax base, congesting local traffic, and taking up land that could be used for highways and more lucrative commercial and residential development. Now, the area was to be a gateway to a revamped downtown and replace the unprofessional-looking farmers' market where, the mayor complained, "most business was conducted from the tailgates of trucks." Emily Dominski, "A Nowhere Between Two Somewheres: The Church Street South Project and Urban Renewal in New Haven" (MSSA Kaplan Prize for Use of MSSA Collections, 2012), 1-3.

51. The activities of the Brookside Home have been chronicled in the pages of the Waterbury Municipal Register, published from 1875 to 1924, as well as in Joseph Anderson, ed., The Town and City of Waterbury, Connecticut, From the Aboriginal Period to the Year Eighteen Hundred and Ninety-Five (New Haven: The Price and Lee Company, 1896), vol. III, 880-85.

52. The municipal slaughterhouse is mentioned in the Municipal Register of the City of Waterbury (Waterbury: Evening Democrat, 1910), 295, and several oral histories, including Charlie Antonelli, interview with author, November 7, 2013; Tony Calli, interview with author, October 30, 2013; and Anthony Dellorfano, interview with author, July 22, 2013.

53. Linder and Zacharias, Of Cabbages, 2.

54. Howard S. Russell, A Long, Deep Furrow: Three Centuries of Farming in New England (1976; repr., Hanover, NH: University Press of New England, 1982). R. Douglas Hurt's, American Agriculture: A Brief History, rev. ed. (West Lafayette: Purdue University Press, 2002) does, however, pay attention to New England and bring the story of farming in the region into the later twentieth century.

55. Brian Donahue, The Great Meadow: Farmers and the Land in Colonial Concord (New Haven: Yale University Press, 2004), 229.

56. Hal Barron, Those Who Stayed Behind: Rural Society in Nineteenth Century New England (Cambridge: Cambridge University Press, 1984); Christopher Clark, The Roots of Rural Capitalism (Ithaca: Cornell University Press, 1990); Donahue, Great Meadow; J. Ritchie Garrison, Landscape and Material Life in Franklin County, Massachusetts, 1770-1860 (Knoxville: University of Tennessee Press, 1991); Richard W. Judd, Second Nature: An Environmental History of New England (Amherst: University of Massachusetts Press, 2014).

57. Barron, Those Who Stayed Behind, is particularly emphatic on this point. See, for example, his discussion in chapter 5, 78-111, about the above average level of residential persistence in Chelsea, Vermont, of farmers and those of their children who inherited their land, and his discussion here and throughout the book of the fact that even many of the landless children chose to stay close to home if possible.

58. See, for example, Clark, Roots of Rural Capitalism, especially chapter 3, 59-117, on the lack of one staple crop for the farmers of Western Massachusetts and the variety of agriculture-related, craft, and manufacturing strategies farm families used to supplement the income they received from raising food including raising broom corn and making brooms. See also Clark's specific discussion of broom making, 100-101, 236-37.

59. See, for example, Judd, Second Nature, 137-40.

60. See, for example, Cathy Stanton, Plant Yourself in My Neighborhood: An Ethnographic Landscape Study of Farming and Farmers in Columbia County, New York (Boston: Northeast Region Ethnography Program, National Park Service, 2012), 51 ff. 
61. Alan L. Olmstead and Paul W. Rhode, Creating Abundance: Biological Innovation and American Agricultural Development (Cambridge: Cambridge University Press, 2008), 350.

62. Judd, Second Nature, 71.

63. Judd, Second Nature, 214.

64. The population would multiply nearly five-fold by 1900 , when it reached almost forty-six thousand, and then more than doubled between then and 1930, when it was above one hundred thousand. See Brecher, Banded Together, 3.

65. 1870 U.S. Census, Waterbury, New Haven County, Connecticut; 1870 U.S. Census, Waterbury, New Haven County, Connecticut, agriculture schedule; 1880 U.S. Census, Waterbury, New Haven County, Connecticut; 1880 U.S. Census, Waterbury, New Haven County, Connecticut, agriculture schedule; accessed through HeritageQuest and Ancestry.com. Waterbury City Directory and Business Advertiser (Hartford: A. Brainerd, 1871) and other volume accessed through Silas Bronson Library at www.bronsonlibrary.org/genealogy and through the Mattatuck Museum, Waterbury, Connecticut, and Ancestry. com.

66. Map of the Town of Waterbury from Actual Survey by H. Irvine (Philadelphia: Richard Clark, 1852), accessed through Waterbury Department of Public Works, http://gis.waterburyct.org/GIS/Map_PDFs/ Historic/1852_WaterburyMap.pdf; "Waterbury, 1874" [specific provenance unknown], Map, Petersen Collection, University of Connecticut Library Map and Geographic Information Center; A. J. Patton, "Map of the City of Waterbury, New Haven County, Connecticut, 1909" and "Map of the City of Waterbury, New Haven County, Connecticut, 1932,” Town Clerk's Office, Waterbury, Connecticut.

67. Note Barron discussion, cited in Note 54, of residential persistence, and Donahue, Great Meadow, with his contention (p. 197) that by 1750 the entire land area of Concord, Massachusetts, had been settled and that (p. 231) almost seven generations of families had worked the same land from the colonial period until well into the nineteenth century. A number of Waterbury's founding families including the Weltons, the Bronsons, and the Warners, could be still found in maps, city directories, and census records as farmers in the late nineteenth century and beyond.

68. Joseph Anderson, ed., The Town and City of Waterbury, Connecticut, from the Aboriginal Period to the Year Eighteen Hundred and Ninety-Five, vol. II (New Haven: Price and Lee, 1896), 194; William Pierpont, interview by author, June 25, 2013. In William Cronon, Nature's Metropolis: Chicago and the Great West (New York: W.W. Norton, 1991), 241-45, Cronon describes how in the late nineteenth century Chicago's "Big Four" meat-packing companies systematically drove butchers out of business in the eastern states.

69. "Enos A. Pierpont" in "Schedule 3, Productions of Agriculture in Waterbury in the County of New Haven, 1870," 3, and "Austin B. Pierpont" in "Schedule 2, Productions of Agriculture in Waterbury in the County of New Haven, 1880," U.S. Selected Federal Census Non-Population Schedules, 18851880. Accessed through Heritagequest.com.

70. As Thomas Lyson says, "A typical farm in the United States in 1870 . . . was very small by today's standards. Most farm families survived on less than seventy-five acres." Lyson, Civic Agriculture, 9.

71. Judd, Second Nature, 132.

72. Judd, Second Nature, 123.

73. "Timothy Porter," Commemorative Biographical Record of New Haven County, vol. II (Chicago: J.H. Beers, 1902), 1537. Silas Bronson Library, Waterbury, CT.

74. Garrison, Landscape and Material Life, 25, 219.

75. Donahue, Great Meadow, 226-28.

76. DuPuis, Nature's Perfect Food, 70, 89, 105.

77. DuPuis, Nature's Perfect Food, is careful to point out (p. 8) that local production or processing does not necessarily mean local ownership or small family farm participation, that in fact (p. 80) milk production became increasingly "oligopolistic" especially after pasteurization became mandatory.

78. Clay McShane and Joel A. Tarr, The Horse in the City: Living Machines in the Nineteenth Century (Baltimore: Johns Hopkins Press, 2007).

79. Cronon, Nature's Metropolis, 384.

80. Ibid., 279.

81. Anderson, Town and City of Waterbury, vol. II, 194; William Pierpont, interview with author, June 24, 2013. 
82. Anderson, Town and City of Waterbury, vol. I, 702-703; Lois Seulowitz, interview with author, January 15,2014 . Sanborn insurance maps of the late nineteenth and early twentieth century show several of these greenhouse operations. One in the southern end of the city is corroborated by a family member, Martha Payne, interview by author, August 22, 2013.

83. Ernest Rasmussen, "The Steward of Malmalic Farm" (unpublished manuscript, n.d.), 198.

84. Waterbury City Directories from the late nineteenth through the middle twentieth century document this trend, and the author is working on GIS maps to illustrate it. Several interviews were conducted by the author with people emblematic of this trend, including wholesale produce vendor Tony Calli, on October 30, 2013; meat vendor Charlie Antonelli, on November 7, 2013; former poultry dealers Walter and Robert Wadman, on August 30, 2013, and former veal dealer Donald Porzio, on October 21, 2013.

85. Antonia (Becce) Padula, interview with author, August 30, 2013; Joanna Clapps Herman, interview with author, June 21, 2013; Beatrice Becce and Beatrice Avcollie, interview with author, June 27, 2013.

86. Leonard Dinnerstein, Roger L. Nichols, and David M. Reimers, Natives and Strangers: A History of Ethnic Americans, 5th ed. (NY: Oxford University Press), 117.

87. Royden Loewen, "Beyond the Monolith of Modernity: New Trends in Immigrant and Ethnic Rural History," Agricultural History 81, no. 2 (Spring 2007): 213.

88. See, for example, Theodore Saloutos, "The Immigrant Contribution to American Agriculture," Agricultural History 50, no. 1 (January 1976): 45-67, which mentions "the reluctance of immigrant farmers to settle in large number in New England" (p. 48), a claim that is curiously undercut by the 1910 and 1920 census figures on the previous page; Kathleen Neils Conzen, "Historical Approaches to the Study of Rural Ethnic Communities," in Ethnicity on the Great Plains, ed. Frederick C. Luebke (Lincoln: University of Nebraska Press, 1980), 1-18.

89. Rudy Favretti, Highlights of Connecticut Agriculture (Storrs: Cooperative Extension Service, College of Agriculture and Natural Resources of the University of Connecticut, 1976), 54.

90. In Russell, A Long, Deep Furrow, 290, 309-10, Howard S. Russell all-too-briefly mentions the turn of the century immigrant groups working in New England as laborers or farm owners. See also Judd, Second Nature, 192, and Stanton, Plant Yourself in My Neighborhood, 176-81, on Polish farmers and farmworkers in upstate New York. Linder and Zacharias, Of Cabbages, explore the racial and ethnic composition of the Brooklyn agricultural work force as a more integral part of their work.

91. Loewen, "Beyond the Monolith of Modernity," 204-27.

92. Theresa De Laurentis, interview with author, October 30, 2013.

93. "Report of the Seventeenth Annual Meeting of the CT Dairymen's Association at Jewell Hall, Hartford, CT, January 18-20, 1898" (Hartford: D.S. Mosely, Printer, 1898), 81. Collection Connecticut Historical Society.

94. "Gray-Haired Patriarchs Run Connecticut Farms," Hartford Courant, June 6, 1920, 3x.

95. "Austin B. Pierpont," Commemorative Biographical Record, vol. II, 1106-107; "Report of the 18th Annual Meeting of the CT Dairymen's Association at Jewell Hall, Hartford, CT, January 18-20, 1899" (Hartford: D.S. Mosely, 1899), 161.

96. Loewen, "Beyond the Monolith of Modernity," 223.

97. Judd, Second Nature, 191-93.

98. Robert and Marie Bosse, interview with author, July 16, 2013; Henry Bosse, interview with author, July 22, 2013.

99. Antonia (Becce) Padula, interview; Beatrice Becce and Beatrice Avcollie, interview; Anthony and Anne Dellorfano, interview with author, July 22, 2013; William Gagliardi, interview with author, June 17, 2013.

100. The aforementioned A. J. Patton maps of Waterbury of 1909 and 1932, prepared for city assessors, show parcels of land and their ownership, giving clear indications of this trend when cross-checked with census records and city directories.

\section{Author Biography}

Ruth Glasser, $\mathrm{PhD}$, is an assistant professor in residence of Urban and Community Studies at the University of Connecticut, Waterbury Campus, and author/developer/curator of books, articles, curriculum materials, oral history projects, and exhibits on Puerto Rican, Dominican, and other ethnic communities in New York and Connecticut. 